\title{
Spatial patterns of infiltration vary with disturbance in a shrub-encroached woodland
}

Stefani Daryanto ${ }^{1}$, David J. Eldridge ${ }^{2,5}$ and Lixin Wang ${ }^{3,4}$

1. Evolution and Ecology Research Centre, School of Biological, Earth and Environmental Science, University of NSW, Sydney, NSW, Australia, 2052

(s.daryanto@student.unsw.edu.au)

2. Office of Environment and Heritage, c/- Australian Wetlands, Rivers and Landscapes Centre, School of Biological, Earth and Environmental Science, University of NSW, Sydney, NSW 2052, Australia (‥eldridge@unsw.edu.au)

3. Department of Earth Sciences, Indiana University-Purdue University, Indianapolis (IUPUI), Indianapolis, IN, 46202, USA (lxwang@iupui.edu)

4. Water Research Centre, School of Civil and Environmental Engineering, University of NSW, Sydney, NSW 2052, Australia

5. Address for correspondence: Phone: 006129385 2194, Fax: 006129385 1558, email: d.eldridge@unsw.edu.au

\begin{abstract}
Woody plant encroachment is known to have substantial effects on a range of ecosystem processes. Research worldwide indicates that the area around shrubs and trees has higher levels of infiltration than the interspaces. Little is known, however, about the hydrological consequences of shrub removal on infiltration, and how this might be influenced by grazing. We examined the spatial patterns of infiltration across three treatments relating to shrub removal and grazing: (i) undisturbed (ungrazed, unploughed), (ii) grazed but unploughed, and (iii) grazed and ploughed. In general we found that disturbance was associated with a greater cover of bare soil but lower infiltrability, our laboratory-based measure of infiltration. At the undisturbed site, bare soil was patchy and localized, with an autocorrelation range or connectivity of $1.4 \mathrm{~m}$. The autocorrelation range of infiltrability at this site $\left(A_{0}=3 \mathrm{~m}\right)$ was larger than would be predicted from the size of the shrub canopy, and this was attributed to the presence of a well-developed understorey layer and biological soil crust community. At both grazed sites, infiltration was confined to the immediate canopy area of the remaining shrubs $\left(A_{0}=1.2 \mathrm{~m}\right.$ in the unploughed-grazed site). Additionally, there was increasing connectivity of bare soil with disturbance, up to $6.8 \mathrm{~m}$ at the ploughed-grazed site. With increasing disturbance, resource-rich shrub patches are likely to become more developed, further reinforcing their growth and persistence at the expense of the bare interspaces. Our results indicate the importance of shrubs for maintaining landscape connectivity, and the
\end{abstract}

This is the author's manuscript of the article published in final edited form as:

Daryanto, S., Eldridge, D. J., \& Wang, L. (2013). Spatial patterns of infiltration vary with disturbance in a shrub-encroached woodland. Geomorphology, 194, 57-64.

http://dx.doi.org/10.1016/j.geomorph.2013.04.012 
long-term unsustainable practice of removal by ploughing, which is likely to promote shrub dominance rather than suppression.

Keywords: grazing, infiltration, encroachment, semi-arid, woodland shrubs, spatial pattern

\section{Introduction}

The proliferation of woody plants (encroachment or thickening) has been widely documented across many of the world's drylands (Ravi et al., 2009; Naito and Cairns, 2011).

Encroachment has substantial effects on ecosystem properties and functions including soil hydrological properties and water balance (Nie et al., 2012). The commonly accepted view is that encroachment leads to higher levels of evapotranspiration compared with grasslands and open woodlands (Scott et al., 2006) and reduced volumes of runoff (Huxman et al., 2005; Nie et al., 2012). As water is a key determinant of productivity in semi-arid systems (Le Houerou et al., 1988; Wang et al., 2012), dryland managers are particularly interested in the long-term effects of different land management practices, including woody plant removal and grazing, on the spatial distribution of soil water, particularly infiltration, as it is the major pathway for the entry of water into the soil. Control of woody plants, therefore, has the potential to yield higher volumes of runoff and therefore enhance water capture for urban and rural land uses (Saleh et al., 2009).

Woody plants are known to a have a strong modifying influence on the physical environment around their canopies through their effects on biotic and abiotic processes (Shachak et al., 2008). The soil around woody plant canopies typically has greater levels of carbon (e.g., Wang et al., 2009), improved physical structure and stability, and greater macroporosity than the surrounding soil matrix (Elkins et al., 1986; Dunkerley, 2000). The infiltration of water is generally greater within patches of woody plants than in the interspaces (e.g., Reid et al., 1999; Bhark and Small, 2003) due to greater litter production and cycling beneath the canopy. Litter moderates evaporative loss of soil moisture and reduces the formation of physical soil crusts by reducing raindrop impact on the surface (Stavi et al., 2009). Enhanced soil moisture and greater litter production beneath woody canopies lead to greater microbial activity and the accumulation of organic matter (Gutiérrez and Jones, 2006).

Apart from their effects on decomposition processes, the cover and distribution of woody plants also have a strong influence on the spatial patterning of soil properties, including infiltration rates, in shrublands and encroached woodlands. Management of these shrublands has the potential, therefore, to alter the spatial distribution of runoff and infiltration and eventually the spatial distribution of soil moisture. For example, removal of woody plants by chaining or cutting can enhance soil moisture (Bates et al., 2000) and may even enhance soil water recharge (e.g., Weltz and Blackburn, 1995). Studies of the effects of woody plant removal in encroached Australian shrublands indicate that physical removal of woody plants and their hummocks by root ploughing leads to a reduction in the number of resourceaccumulating patches and an increase in inter-patch distance (Daryanto and Eldridge, 2010). Grazing-induced disturbance is known to fragment soil biological cover that occurs in the interspaces and lead to destabilization of surface soil aggregates (Daryanto and Eldridge, 2010). Grazing-induced trampling has been shown to reduce infiltration rates through surface compaction (Castellano and Valone, 2007), but little is known of the joint effects of grazing and soil disturbance associated with the physical shrub removal, on soil surface condition and infiltration processes. 
The aim of the study reported here is to examine the spatial arrangement of soil infiltration in relation to physical shrub removal, with and without grazing-induced disturbance, based on data from a semi-arid, shrub-encroached woodland in eastern Australia. We hypothesized that grazing and shrub removal by ploughing would alter the spatial distribution of infiltration, cover of bare soil and bulk density, and that with increased disturbance, infiltration would be concentrated more strongly in the area around the shrubs. Specifically, we expected that grazing and/or ploughing would increase the connectivity of patches of bare soil, but create localized patches of more porous soil around shrubs, resulting in reduced connectivity of infiltrability. We also expected that infiltrability would decline with increasing distance from shrub canopies, particularly at disturbed sites, in response to a reduction in cover of litter and biological soil crusts and increases in bare soil cover and bulk density.

\section{Methods}

\subsection{Study site}

The study was conducted at Wapweelah, an extensive grazing property near Bourke in northwestern New South Wales, Australia (29 $16^{\circ}$ 'S, $145^{\circ} 26^{\prime} \mathrm{E}$ ) which experienced shrub encroachment. The site falls within Gumbalie Land System (Walker, 1991), which is characterized by sparse perennial grasses but dense native shrubs such as turpentine (Eremophila sturtii), narrow-leaf hopbush (Dodonaea viscosa var. angustissima), green turkey bush (Eremophila gilesii), and budda (Eremophila mitchellii) with scattered trees of mulga (Acacia aneura), ironwood (Acacia excelsa), bimble box (Eucalyptus populnea) and wilga (Geijera parviflora). The sandplain unit is mostly level, undulations are scant and if any, the slopes are less than $1 \%$. The soils are sandy red earths with sandy loam to loamy texture. Annual rainfall is approximately $312 \mathrm{~mm}$ with 45\% more rain falls during six warmer months than the cooler months (Robson, 1995).

\subsection{Experimental design}

In 1990, one area (200 m x $400 \mathrm{~m}$ ) was established and divided into four blocks of 200 wide long by $100 \mathrm{~m}$ wide. Two of the four blocks were then enclosed in a 6-m high, herbivoreproof fence while the unfenced blocks were subject to grazing by domestic stock and other herbivores (e.g., kangaroos, camels, goats, and rabbits). One of both the fenced and unfenced blocks was then ploughed with a single pass of a $4.2 \mathrm{~m}$ wide single-tyned 'Stationmaster' blade plough pulled by a $90 \mathrm{~kW}$ crawler tractor (Robson, 1995), while the remaining blocks were left unploughed. This design resulted in four grazing by ploughing treatments: ploughed and grazed, ploughed and ungrazed, unploughed and grazed, and, unploughed and ungrazed. We did not undertake any measurements in the ploughed-ungrazed treatment as we were interested in potential effects on shrublands more broadly, and the ploughed-ungrazed strategy is, to our knowledge, unlikely to be adopted by land managers. The treatments represented a gradient in disturbance from most disturbed (ploughed-grazed) to least disturbed (unploughed-ungrazed).

Within each of the three treatments, we established a $10 \mathrm{~m}$ x $10 \mathrm{~m}$ plot and sampled the surface on a coarse $2 \mathrm{~m}$ grid $(n=36)$ as well as a finer grid of points that were spaced at distances of $25 \mathrm{~cm}$ apart $(n=72)$ across the plot $(n=108$ in total). For each sampling point, we recorded its distance to the canopy of the nearest shrub or tree, and estimated the surface coverage of bare ground using a small quadrat of 25 grid points. Soil, sampled using an intact soil corer of $5.7 \mathrm{~cm}$ diameter $\mathrm{x} 7 \mathrm{~cm}$ depth, was collected at each of the 108 points and air 
dried at constant temperature and humidity before the bulk density and infiltration measurements were made. We used as our measure of infiltration a laboratory-derived index of infiltrability which is based on a syringe method (Mills et al., 2006).

\subsection{Calculation and data analysis}

For each plot, descriptive statistics (i.e., mean, median, standard deviation and coefficient of variance) were performed to indicate the overall variability for each observed variables (i.e., bare ground, bulk density and infiltrability). Kruskal-Wallis and post-hoc tests were performed to indicate if significant difference occurred among the treatments. A correlation matrix for those variables was calculated using a modified $t$-test (PASSAGE software; http://www.passagesoftware.net), which corrects the degrees of freedom based on the amount of auto-correlation in the data (e.g., Wang et al., 2007). Point biserial correlation was also performed to examine potential relationships between shrub cover (i.e. under the canopy vs the open) and those observed variables.

Spatial patterns in the infiltrability index in relation to the disturbance gradient were examined using semivarigrams with the $\mathrm{GS}^{+}$geostatistical package (Gamma Design Software, Michigan, USA). We compared isotropic and corresponding anisotropic semivariograms at $0^{\circ}, 45^{\circ}, 90^{\circ}$, and $135^{\circ}$ and did not find any significant directional pattern. We therefore used isotropic variograms in all analyses. We also ensured that all data were normally distributed, which is a prerequisite in geostatistical theory, by conducting the normal-score transformation prior to analyses (Rossi et al., 1993). Parameters derived from the semivariograms were used to quantify three key aspects of patchiness in the distribution of each of the variables: (i) variability that occurs at a scale less than the sampling scale and the magnitude of spatial dependence (i.e., the degree to which patches are differentiated from the surrounding area by their distinct, within-patch homogeneity), (ii) the mean diameter of those patches (e.g., Rodríguez et al., 2009; Li et al., 2010), and to a lesser extent, (iii) the arrangement of patches across the plot (Augustine and Frank, 2001). The variability less than the sampling scale was obtained using the nugget variance $\left(C_{0}\right)$ while the magnitude of spatial structure calculated using the index of $C /\left(C_{0}+C\right)$. A greater proportion of the total sample is spatially structured if the index approaches unity. The mean diameter of patches and the arrangement of patches across the plot were determined by the distance separating sampling points at which semivariance reaches an asymptote or the autocorrelation range $(A)$. There are several commonly used semivariogram models and spherical model is often used in ecological studies (Schlesinger et al., 1996; Wang et al., 2009). This model was used to facilitate the comparison between the observed variables under different treatments, and was chosen because it is consistent with the distribution of those variables based on three criteria: high $r^{2}$, minimal extrapolation of semivariance at spatial scale $<25 \mathrm{~cm}$ (our smallest sampling scale), and the fitted model shape (Wang et al., 2007).

To test the relationship between the distance to canopy and the observed soil properties, the segmented quantile regression was performed. An envelope that includes the extreme responses of a variable to a single factor could therefore be the only meaningful feature to explain the relationship between distance to canopy and soil properties. However, modelling the envelope by $99 \%$ quantile, for example, may lead to 'biased results as potential errors in the response variable have different influence depending on the direction of deviation' (Schröder et al., 2005). We therefore used the 95\% quantiles to obtain a compromise between the envelope and the influence of measurement error (Schröder et al., 2005). Segmented quantile regression involved the subdivision of data into segments to ensure that there was 
sufficient number of segments and data points within each segment to reflect the distribution of the response variable (i.e., bare ground cover, bulk density and infiltrability) over the particular range of independent variable (i.e., distance to canopy; Koenker and Hallock, 2001). We applied the segmented quantile regression because it is less affected by the presence of outliers than the common non-linear quantile regressions (e.g., Mills et al., 2006). We divided our data into nine classes of equal size $(n=12)$, which were then sorted in ascending order, and parametric regression used to fit a line or curve through the $95 \%$ quantiles of each class. The regression line with the greatest $r^{2}$ value was selected from first and second order polynomial, logarithmic, exponential and power relationship. Segmented quantile regression analyses were performed using Sigmaplot version 11.0 and the $95 \%$ quantiles were determined using Microsoft Excel 2003. Details of the segmented quantile method are given in Mills et al. (2006) and Medinski et al. (2010).

\section{Results}

\subsection{Univariate analysis}

We detected significant difference in the cover of bare ground (Kruskal-Wallis; $\mathrm{H}_{2}=166.42$, $P<0.01, n=108)$, bulk density $\left(H_{2}=66.78, P<0.01\right)$, and infiltrability $\left(H_{2}=32.34, P<\right.$ $0.01)$ among the three treatments varying in levels of disturbance. The mean and median values of bare ground increased with increasing disturbance from $7.8 \%$ and $0 \%$ at the least disturbed (unploughed-ungrazed) to $74.4 \%$ and $87.5 \%$ at the most disturbed (ploughedgrazed) site. The variability of bare ground, however, showed an opposite trend. The highest coefficient of variability (CV) was observed at the unploughed-ungrazed site (252.3\%) while the lowest CV was at the ploughed-grazed site (41.4\%). Mean infiltrability was greatest at the unploughed-ungrazed site, with the lowest variability. Bulk density was greatest at the ploughed-grazed site, and variability was lower at the two unploughed sites, which had similar values (Table 1). We also recorded, but only at the unploughed-grazed site, positive correlation between bare ground and bulk density as well as negative correlation between bulk density and infiltrability (Table 2).

\subsection{Spatial analysis of bare soil, bulk density and infiltrability}

Consistent with our hypothesis, bare ground was highly patchy and localized $\left(A_{0}=1.4 \mathrm{~m}\right)$ at the unploughed-ungrazed site, in contrast to that at the disturbed sites (Figures 1a-1c). The connectivity between patches of bare ground increased with either grazing or ploughing. This was indicated by the longer autocorrelation range at the unploughed-grazed $(3.0 \mathrm{~m})$ and the ploughed-grazed site $(6.9 \mathrm{~m})$. We also found higher nugget variances at these disturbed sites (Figures $1 b$ \& 1c) than that at the undisturbed site (Figure 1a), indicating higher small-scale variability occurred with grazing and ploughing. There was a decreasing trend of bare ground cover with increasing distance from shrub or tree canopy at the unploughed-ungrazed site, but consistent increase beyond the shrub canopy at both grazed sites (Figure 1d-1f). The presence of shrubs, however, was correlated with the presence of bare ground only at the unploughedungrazed site (Table 3).

Unlike bare ground $\left(C /\left(C+C_{o}\right)=0.92\right.$; Figure 1a), we did not find strong spatial structure in bulk density $\left(C /\left(C+C_{o}\right)=0.50\right.$; Figure $\left.2 a\right)$ at the unploughed-ungrazed site. Instead, there was evidence of high connectivity and high small-scale variability in bulk density, indicated by the long autocorrelation range $(2.5 \mathrm{~m})$ and high $C_{0}(0.40$; Figure $2 \mathrm{a})$. The trend, however, was different at the unploughed-grazed site, where bulk density exhibited a stronger spatial 
structure $\left(C /\left(C+C_{0}\right)=0.75\right)$ but a decline in its autocorrelation range ( $A_{0}=1.8 \mathrm{~m}$; Figure $\left.2 \mathrm{~b}\right)$, similar to the autocorrelation range of shrub cover ( $1.9 \mathrm{~m}$; Daryanto et al., in press). The autocorrelation range of bulk density at the ploughed-grazed site was even shorter than that at the unploughed-grazed site $(1.2 \mathrm{~m})$, with high small-scale variability $\left(C_{0}=0.42\right.$; Figure $\left.2 \mathrm{c}\right)$. There was only slight increase in bulk density beyond plant canopy at the unploughedungrazed site (Figure 2d), but higher increases at both grazed sites (Figure 2e \& 2f). Overall, a high shrub cover was associated with a low bulk density (Table 3).

The importance of shrubs in determining infiltration, by creating patches of low density soil, was reflected at the autocorrelation range of infiltrability. The autocorrelation range of infiltrability changed in relation to ploughing and grazing (Figure 3a-3c). The semivariogram of infiltrability at the undisturbed site (unploughed-ungrazed) had a high autocorrelation range ( $3 \mathrm{~m}$ ) and high small-scale variability, indicated by nugget variance of 0.45 (Figure 3a). In contrast, infiltrability under the unploughed-grazed treatment was highly spatially structured $\left(C /\left(C+C_{o}\right)=0.83\right)$ and was autocorrelated at distances of about $1.2 \mathrm{~m}$ (Figure 3b), which corresponded to the zone of maximum biological activity of the shrubs. Under the same treatment, there was a relatively rapid decline in infiltrability with distance from the canopy, with the sharpest decline close to $(<0.5 \mathrm{~m})$ shrub canopies (Figure 3e). Conversely, there was only a slight decline in infiltrability with increasing distance from the canopy at the ungrazed site (Figure 3d). This trend, supported by our correlation results (Table 3), indicated that under grazing, infiltration was restricted to the area in the immediate vicinity of the canopy. Both connectivity and small-scale variability in infiltrability were higher under the ploughed-grazed than the unploughed-grazed treatment (Figure 3b \& 3c). We also noted rapid decline in infiltrability with increasing distance from canopy under the ploughed-grazed treatment (Figure 3f).

\section{Discussion}

Plants are known to affect soil hydrology in various ecosystems, such as in the sub-alpine (Merz et al., 2009) and Mediterranean grasslands (Pueyo et al., in press) through biologicallymediated processes such as litter production and changes in vegetation composition. In the more arid region, such effects are more profound, as perrenial plants modify the spatial patterning of soil properties, including water flow. Global research in this area has shown that infiltration is generally greater under the canopies of perennial plants than in their interspaces (Bhark and Small, 2003; Muñoz-Robles et al., 2011; Stavi et al., 2008). Our research showed that the pattern of infiltrability, our surrogate for infiltration, changed with disturbance. Infiltrability at the undisturbed site remained high beyond shrub canopy, but this was not the case at the disturbed sites. This pattern indicated that there was an abrupt change in properties between soils beneath the canopy and in the interspaces at the disturbed sites, but only gradual changes at the undisturbed site. The dichotomy between shrubs and their interspaces thus seemed to be more intense with disturbance due to the absence of understorey plants and biological crust cover. Consequently, the importance of shrubs as loci for infiltration increases with increasing disturbance.

\subsection{Hydrological processes in the undisturbed site}

Consistent with our hypothesis, the undisturbed site (i.e., unploughed-ungrazed) had the longest autocorrelation range of infiltrability, corresponding to that of bulk density. We observed that surfaces beneath shrub canopies in the least-disturbed area were generally well-vegetated with perennial grasses and forbs, which would have led to a reduction in bulk 
density out from the shrub canopies (Muñoz-Robles et al., 2011), resulting in zones of higher infiltration beyond the canopy. Enhanced soil porosity would be expected in the absence of livestock trampling, which has been shown to lead to distinct patterns of areas with high bulk density and low infiltration (Andrew and Lange, 1986; Stavi et al., 2008), and could also contribute to the weak decline in infiltrability up to $150 \mathrm{~cm}$ away from the shrub canopy (Figure 3d). Such a trend was not observed at both grazed sites, which exhibited a rapid decline in infiltrability within $25 \mathrm{~cm}$ of the edge of the canopy (Figure 3e \& 3f).

About half of the variation in bulk density and infiltrability at the undisturbed site occurred at a scale $<25 \mathrm{~cm}$, which corresponded to our highest sampling resolution. Such variation might occur due to small-scale variability in: (i) rainfall interception by shrubs, (ii) litter cover and depth, and (iii) biological crust cover. Bare soils exposed to direct raindrops are susceptible to raindrop impact from the foliage, which results in effects ranging from dislodgement of soil particles to widespread compaction (Geddes and Dunkerley, 1999). Rainfall interception by shrubs might moderate those effects, though some raindrops will penetrate the canopy. Variability in interception is likely affected by shrub morphology, with densely-arranged canopies able to intercept more rainfall than those with a sparsely-arranged canopy (Archer et al., 2012; Bochet et al., 1998; Cowling and Mills, 2011). Variation in morphology also determines the ability of shrubs to retain litter (Bochet et al., 1998), likely creating small-scale, uneven distribution of litter under and around their canopy. Sub-canopy litter has been shown to alter the effect of raindrops by dissipating raindrop energy, thereby minimizing rainsplash that would lead to soil crusting (Geddes and Dunkerley, 1999). By increasing organic material, localized deposits of litter could also lead to reductions in bulk density and therefore increased infiltration (Shukla et al., 2006). A thick cover of litter could also serve as a microterrace or litter dam, retaining water and reducing the likelihood of runoff (Eddy et al., 1999). Indeed, our data indicated that there was a close association between the autocorrelation range of litter cover ( $2.4 \mathrm{~m}$; Daryanto et al., in press) and infiltrability ( $3 \mathrm{~m}$; Figure 3a) at this site.

Finally, the presence of a well-developed matrix of cryptogamic crusts in the shrub interspaces at this undisturbed site (Daryanto and Eldridge, 2010) and small patches of bare soil would have created microsites of enhanced water ponding and reduced the time to initiation of runoff (Eldridge et al., 2010), eventually leading to an increase in infiltration in the zone immediately surrounding the canopy. Although some types of cryptogamic crusts (e.g. thin and smooth crusts) have been known to generate run-off due to their waterrepellency properties (Yair, 1990), some others could actually increase water retention by forming micro-catchments (Yair et al., 2011), analogous to litter dams. Increasing structural development of biological crust cover, generally characterized by thicker and darker-colored crusts, has been recorded to improve soil water-absorbing capacity (Madsen et al., 2008). Their composition, however, might be random, likely generating high infiltration variability at small scale.

\subsection{Changes of hydrological processes with grazing and ploughing}

Although grazing and ploughing both increased the autocorrelation range of bare ground and reduced that of bulk density, the spatial patterning of infiltrability differed between the unploughed-grazed and ploughed-grazed sites. At the unploughed-grazed site, we detected a strong spatial dependence, but short autocorrelation range, of soil infiltrability (Figure 3b), indicating that infiltration was restricted to the area around the margins of the shrubs. Indeed, at the unploughed-grazed site, the autocorrelation range for bulk density ( 1.8 $\mathrm{m})$ and 
infiltrability ( $\sim 1.2 \mathrm{~m}$ ) was similar to that of shrub cover ( $1.9 \mathrm{~m}$; Daryanto et al., in press). At the more disturbed ploughed-grazed site, however, the spatial dependence of infiltrability was weak, but it had a long autocorrelation range, suggesting that small cohort of shrubs, rather than single, mature shrubs, might be responsible for the variability in infiltrability. This is consistent with our data indicating a distribution of shrub sizes tending to younger smaller shrubs of higher density at the ploughed-grazed compared with the unploughed-grazed site (Daryanto and Eldridge, 2010).

We also observed a more gradual decline in infiltrability beyond the canopy at the ploughedgrazed than the unploughed-grazed site. Elevated levels of infiltrability just beyond the canopy comparable with levels under the canopy suggest that plant roots were responsible, to some extent for the increased infiltration (Segoli et al., 2008). Differences in infiltrability could also be due to differences in the size or age of individual shrubs. Given that the ploughed-grazed site was dominated by young, shorter shrubs (Daryanto and Eldridge, 2010), they are likely to have more lateral, surface-feeding roots than the larger, older shrubs, thus extending the area over which they are likely to scavenge for water to areas beyond their canopy. Since the development of plant roots would adjust to the availability of limiting resources such as water and nitrogen (February et al., 2011), we would expect that newlyregenerating plant roots in the ploughed-grazed area would be closer to the soil surface due to limited soil nutrients and most probably infiltration depth in the interspace (Daryanto et al., 2012).

While there was close association between the autocorrelation range for litter cover and infiltrabilty at the undisturbed site, we found that at both grazed sites the autocorrelation range of litter cover ( $4.5 \mathrm{~m}$; Daryanto et al., in press) did not correspond with that of infiltrabililty. The weak litter effect might be due to dispersion by livestock, and/or scattering of litter into the interspaces by wind or water ( $\mathrm{Li}$ et al., 2008). This scattering greatly diminishes the ecosystem effects of litter such as its capacity to reduce the energy of gravity drops (Geddes and Dunkerley, 1999), form resource-attenuating litter dams (Eddy et al., 1999; Lechmere-Oertel et al., 2005) or improve infiltration rates (Dunkerley, 2000).

Infiltrability on the two disturbed treatments instead was autocorrelated at distances of 1.2 to $3.5 \mathrm{~m}$, closer to that of shrub cover (1.9 m; Daryanto et al., in press). This is also supported by the high positive correlation between infiltration and shrub cover at the disturbed sites (Table 3). In heavily grazed area, trampling generally leads to increased soil compaction and bulk density, except for areas around the shrubs (Stavi et al., 2008) and therefore restricting infiltration only to under-canopy areas. Similarly, both ploughing and grazing limited infiltrability in the interspaces by reducing biological soil crust cover, which has been shown to improve soil infiltrability (Eldridge et al., 2010). Clearly grazing- and ploughing-induced disturbances have substantial impacts on soil surface cover types, altering their distribution, and ultimately affecting the infiltration of water in the interspaces beyond the shrub canopies.

Our results showed that the autocorrelation range of bulk density was slightly smaller, but that of bare areas was much larger, at the ploughed-grazed than the unploughed-grazed site. These results were unsurprising, given that the ploughed-grazed site was dominated by small shrubs, and the area beyond the canopy was typically bare and unvegetated, often due to ploughing. The greater distances between patches in the ploughed area was apparent, even two decades after ploughing (Daryanto and Eldridge, 2010). Shrub-free (bare) interspaces experience higher surface temperatures and evapotranspiration, reduced organic matter incorporation, denitrification, ammonia volatilization, and increased erosion (Schlesinger et al., 1990). The formation of physical soil crusts due to direct raindrop impacts reduces water 
availability in the interspaces, further decreased possible plant establishment (Holmgren, 2009). A similar trend has been observed in Mediterranean systems where small vegetation patches and a large cover of bare soil were negatively correlated with soil sorptivity (Pueyo et al., in press). Grazing-induced disturbances reinforce the differences between shrubs and their interspaces, with eroded sediment and airborne nutrients accumulating under shrub canopies due to wind and water processes ( $\mathrm{Li}$ et al., 2009). In addition, increased infiltration beneath shrub canopies, enhanced micro- and macroarthropod activity (Doblas-Miranda et al., 2009) and therefore decomposition processes promote a new set of positive feedbacks between shrubs and the remaining bare ground (Holmgren, 2009), where shrub growth is promoted at the expense of plants in the interspaces. We summarize the processes that were affected by grazing and/or ploughing in a conceptual model (Figure 4a). Small-scale feedbacks will have consequences at larger spatial scales (e.g., the landscape-scale). Grazing and/or ploughing create a more localized infiltration, which is confined to individual shrub canopies. These localized canopy effects when scaled up to the landscape scale will likely change ecosystemlevel water balance by altering patterns of evaporation and runoff (Figure 4b).

\subsection{Concluding remarks}

Our findings demonstrate the marked changes in our measure of soil infiltration and soil physical properties in relation to woody canopies under different levels of disturbance. While the effect of shrubs on infiltration extended beyond the canopy at the undisturbed site, it was concentrated close to the canopy at sites that were disturbed. Similarly, the rate of change in soil physical properties out from woody plant canopies increased markedly with increasing disturbance. Increasing disturbance therefore reinforces the difference between shrubs and their interspaces by restricting the effects of shrubs on soil processes to the immediate vicinity of their canopies. The effect of this disturbance is therefore to reinforce the shrubdominant state by preventing the movement of resources to the interspaces. Maintaining existing patches of perennial woody vegetation is therefore critical for preserving high levels of connectivity between shrubs and their interspaces and for increasing landscape-level values of infiltration. The importance of vegetation effects, including reducing soil temperature, improved soil parameters and enhanced infiltration rates, are consistent in other pastoral system (e.g., rotational grazing) and even system characterized by regular fires (Teague et al., 2010). Our results highlight therefore the importance of shrubs for maintaining hydrological processes in drylands. Severe disturbances such as shrub removal and overgrazing, however, will only result in reduced areas of high infiltration, altering the spatial distribution of water and potentially leading to greater runoff and resource loss.

\section{Acknowledgments}

The exclosures were originally established by David Robson under funding from the NSW Government's Environmental Trust Fund. We are grateful to the owners and managers of 'Wapweelah' for allowing us access to their property and for maintaining the exclosures. We thank Niki Huang and Alex James for assistance with field sampling, and Terry Koen and Bryce Kelly for sharing their knowledge of statistic analyses. This study was supported by a PhD scholarship from AusAID. Lixin Wang was partially supported by a Vice-Chancellor's Postdoctoral Research Fellowship from the University of New South Wales.

\section{References}


Andrew, M.H., Lange, R.T., 1986. Development of a new piosphere in arid chenopod shrubland grazed by sheep.1. Changes to the soil surface. Australian Journal of Ecology 11, 395-409.

Archer, N.A.L., Quinton, J.N., Hess, T.M., 2012. Patch vegetation and water redistribution above and below ground in south-east Spain. Ecohydrology 5, 108-120.

Augustine, D.J., Frank, D.A., 2001. Effects of migratory grazers on spatial heterogeneity of soil nitrogen properties in a grassland ecosystem. Ecology 82, 3149-3162.

Bates, J.D., Miller, R.F., Svejcar, T.J., 2000. Understory dynamics in cut and uncut western juniper woodlands. Journal of Range Management 53, 119-126.

Bhark, E.W., Small, E.E., 2003. Association between plant canopies and the spatial patterns of infiltration in shrubland and grassland of the Chihuahuan Desert, New Mexico. Ecosystems 6, 185-196.

Bochet, E., Rubio, J.L. and Poesen, J., 1998. Relative efficiency of three representative matorral species in reducing water erosion at the microscale in a semi-arid climate (Valencia, Spain). Geomorphology 23, 139-150.

Castellano, M.J., Valone, T.J., 2007. Livestock, soil compaction and water infiltration rate: Evaluating a potential desertification recovery mechanism. Journal of Arid Environments 71, 97-108.

Cowling, R.M., Mills, A.J., 2011. A preliminary assessment of rain throughfall beneath Portulacaria afra canopy in subtropical thicket and its implications for soil carbon stocks. South African Journal of Botany 77, 236-240.

Daryanto, S., Eldridge, D.J., 2010. Plant and soil surface responses to a combination of shrub removal and grazing in a shrub-encroached woodland. Journal of Environmental Management 91, 2639-2648.

Daryanto, S., Eldridge, D.J., Koen, T.B., 2012. Soil nutrients under shrub hummocks and debris mounds two decades after ploughing. Plant and Soil 351, 405-419.

Daryanto, S., Eldridge, D.J., Wang, L., in press. Ploughing and grazing alter the spatial patterning of surface soils in a shrub-encroached woodland. Geoderma, in press.

Doblas-Miranda, E., Sánchez-Pinero, F. and González-Megías, A., 2009. Different microhabitats affect soil macroinvertebrate assemblages in a Mediterranean arid ecosystem. Applied Soil Ecology 41, 329-335.

Dunkerley, D.L., 2000. Assessing the influence of shrubs and their interspaces on enhancing infiltration in arid Australian shrubland. The Rangeland Journal 22, 58-71.

Eddy, J., Humphreys, G.S., Hart, D.M., Mitchell, P.B., Fanning, P.C., 1999. Vegetation arcs and litter dams: similarities and differences. Catena 37, 57-73.

Eldridge, D.J., Bowker, M.A., Maestre, F.T., Alonso, P., Mau, R.L., Papadopulos, J., Escudero, A., 2010. Interactive effects of three ecosystem engineers on infiltration in a semi-arid Mediterranean grassland. Ecosystems 13, 499-510.

Elkins, N.Z., Sabol, G.V., Ward, T.J., Whitford, W.G., 1986. The influence of subterranean termites on the hydrological characteristics of a Chihuahuan desert ecosystem. Oecologia 69, 521-528.

February, E.C., Allsopp, N., Shabane, T., Hattas, D., 2011. Coexistence of a C4 grass and a leaf succulent shrub in an arid ecosystem. The relationship between rooting depth, water and nitrogen. Plant and Soil 349, 253-260.

Geddes, N., Dunkerley, D., 1999. The influence of organic litter on the erosive effects of raindrops and of gravity drops released from desert shrubs. Catena 36, 303-313.

Gutiérrez, J.L., Jones, C.G., 2006. Physical ecosystem engineers as agents of biogeochemical heterogeneity. Bioscience 56, 227-236. 
Holmgren, M., 2009. Dryland dynamics and resotration: Perspectives for the use of climatic swings. In: Hobbs, R.J., Suding, K.N. (Eds), New Models for Ecosystem Dynamics and Restoration. Island Press, Washington, DC, pp. 112-123.

Huxman, T.E., Wilcox, B.P., Breshears, D.D., Scott, R.L., Snyder, K.A., Small, E.E., Hultine, K., Pockman, W.T., Jackson, R.B., 2005. Ecohydrological implications of woody plant encroachment. Ecology 86, 308-319.

Koenker, R., Hallock, K.F., 2001. Quantile regression. Journal of Economic Perspectives 15, 143-156.

Lechmere-Oertel, R.G., Cowling, R.M., Kerley, G.I.H., 2005. Landscape dysfunction and reduced spatial heterogeneity in soil resources and fertility in semi-arid succulent thicket, South Africa. Austral Ecology 30, 615-624.

Le Houérou, H.N., Bingham, R.L., Skerbek, W., 1988. Relationship between the variability of primalry production and the variability of annual precipitation in world arid lands. Journal of Arid Environments 15, 1-18.

Li, J., Okin, G.S., Alvarez, L., Epstein, H., 2008. Effects of wind erosion on the spatial heterogeneity of soil nutrients in two desert grassland communities. Biogeochemistry 88, 73-88.

Li, J., Okin, G.S., Alvarez, L.J., Epstein, H.E., 2009. Sediment deposition and soil nutrient heterogeneity in two desert grassland ecosystems, southern New Mexico. Plant and Soil 319, 67-84.

Li, J., Richter, D.d., Mendoza, A., Heine, P., 2010. Effects of land-use history on soil spatial heterogeneity of macro- and trace elements in the Southern Piedmont USA. Geoderma 156, 60-73.

Madsen, M.D., Chandler, D.G., Belnap, J., 2008. Spatial gradients in ecohydrologic properties within a pinyon-juniper ecosystem. Ecohydrology 1, 349-360.

Medinski, T.V., Mills, A.J., Esler, K.J., Schmiedel, U., Jurgens, N., 2010. Do soil properties constrain species richness? Insights from boundary line analysis across several biomes in south western Africa. Journal of Arid Environments 74, 1052-1060.

Merz, A., Alewell, C., Hiltbrunner, E., Bänninger, D., 2009. Plant-compositional effects on surface runoff and sediment yield in subalpine grassland. Journal of Plant Nutrition and Soil Science 176, 777-788.

Mills, A.J., Fey, M.V., Grongroft, A., Petersen, A., Medinski, T.V., 2006. Unravelling the effects of soil properties on water infiltration: segmented quantille regression on a large data set from arid south-west Africa. Australian Journal of Soil Research 44, 783-797.

Muñoz-Robles, C., Reid, N., Tighe, M., Briggs, S.V., Wilson, B., 2011. Soil hydrological and erosional responses in patches and inter-patches in vegetation states in semi-arid Australia. Geoderma 160, 524-534.

Naito, A.T., Cairns, D.M., 2011. Patterns and processes of global shrub expansion. Progress in Physical Geography 35, 423-442.

Nie, W., Yuan, Y., Kepner, W., Erickson, C., Jackson, M., 2012. Hydrological impacts of mesquite encroachment in the upper San Pedro watershed. Journal of Arid Environments 82, 147-155.

Pueyo, Y., Moret-Fernández, D., Saiz, H., Bueno, C. G., and Alados, C. L., 2012. Relationships between plant spatial patterns, water infiltration capacity, and plant community composition in semi-arid Mediterranean ecosystems along stress gradients. Ecosystems, in press.

Reid, K.D., Wilcox, B.P., Breshears, D.D., MacDonald, L., 1999. Runoff and erosion in a pinon-juniper woodland: Influence of vegetation patches. Soil Science Society of American Journal 63, 1869-1879. 
Ravi, S., D’Odorico, P., Wang, L., White, C.S., Okin, G.S., Macko, S.A., Collins, S.L., 2009. Post-fire resource redistribution in desert grasslands: a possible negative feedback on land degradation. Ecosystems 12, 434-444.

Robson, A.D., 1995. The effects of grazing exclusion and blade-ploughing in semi-arid woodland vegetation in north-western New South Wales over 30 months. Rangeland Journal 17, 111-127.

Rodríguez, A., Durán, J., Fernández-Palacios, J.M., Gallardo, A., 2009. Spatial pattern and scale of soil $\mathrm{N}$ and $\mathrm{P}$ fractions under the influence of a leguminous shrub in a Pinus canariensis forest. Geoderma 151, 303-310.

Rossi, R.E., Borth, P.W., Tollefson, J.J., 1993. Stochastic simulation for characterizing ecological spatial patterns and appraising risk. Ecological Applications 3, 719-735.

Saleh, A., Wu, H., Brown, C.S., Teagarden, F.M., McWilliams, S.M., Hauck, L.M., Millican J.S., 2009. Effect of brush control on evapotranspiration in the North Concho River watershed using the eddy covariance technique. Journal of Soil and Water Conservation 64, 336-349.

Schlesinger, W.H., Reynolds, J.F., Cunningham, G.L., Huenneke, L.F., Jarrell, W.M., Virginia, R.A., Whitford, W.G., 1990. Biological feedbacks in global desertification. Science 247, 1043-1048.

Schlesinger, W.H., Raikes, J.A., Hartley, A.E., Cross, A.F., 1996. On the spatial pattern of soil nutrients in desert ecosystem. Ecology 77, 364-374.

Schröder, H.K., Andersen, H.E., Kiehl, K., 2005. Rejecting the mean: Estimating the response of fen plant species to environmental factors by non-linear quantile regression. Journal of Vegetation Science 16, 373-382.

Scott, R.L., Huxman, T.E., Williams, D.G., Goodrich, D.C., 2006. Ecohydrological impacts of woody-plant encroachment: Seasonal patterns of water and carbon dioxide exchange within a semiarid riparian environment. Global Change Biology 12, 311324.

Segoli, M., Ungar, E.D., Shachak, M., 2008. Shrubs enhance resilience of a semi-arid ecosystem by engineering and regrowth. Ecohydrology 1, 330-339.

Shachak, M., Boeken, B., Groner, E., Kadmon, R., Lubin, Y., Meron, E., Ne’eman, J., Perevolotsky, A., Shkedy, Y., Ungar, E.D., 2008. Woody species as landscape modulators and their effect on biodiversity patterns. Bioscience 58, 209-221.

Shukla, M.K., Lal, R., Ebinger, M., Meyer, C., 2006. Physical and chemical properties of soils under some piñon-juniper-oak canopies in a semi-arid ecosystem in New Mexico. Journal of Arid Environments 66, 673-685.

Stavi, I., Ungar, E.D., Lavee, H., Sarah, P., 2008. Grazing-induced spatial variability of soil bulk density and content of moisture, organic carbon and calcium carbonate in a semiarid rangeland Catena 75, 288-296.

Stavi, I., Lavee, H., Ungar, E.D., Sarah, P., 2009. Ecogeomorphic feedbacks in semiarid rangelands: A review. Pedosphere 19, 217-229.

Teague, W. R., Dowhower, S. L., Baker, S. A., Ansley, R. J., Kreuter, U. P., Conover, D. M., Waggoner, J. A., 2010. Soil and herbaceous plant responses to summer patch burns under continuous and rotational grazing. Agriculture, Ecosystems and Environment 137, 113-123.

Walker, P.J., 1991. Land Systems of Western New South Wales, Soil Conservation Service of New South Wales.

Wang, L., Mou, P.P., Huang, J., Wang, J., 2007. Spatial heterogeneity of soil nitrogen in a subtropical forest in China. Plant and Soil 295, 137-150.

Wang, L., Okin, G.S., Caylor, K.K., Macko, S.A., 2009. Spatial heterogeneity and sources of soil carbon in southern African savannas. Geoderma 149, 402-408. 
Wang, L., D'Odorico, P., Evans, J.P., Eldridge, D.J., McCabe, M.F., Caylor, K.K., King, E.G. 2012. Dryland ecohydrology and climate change: critical issues and technical advances. Hydrology and Earth System Sciences 16, 2585-2603.

Weltz, M.A., Blackburn, W.H., 1995. Water budget for south Texas rangelands. Journal of Range Management 48, 45-52.

Yair, A., 1990. Runoff generation in a sandy area - The Nizzana sands, Western-Negev, Israel. Earth Surface Processes and Landforms 15, 597-609.

Yair, A., Almog, R., Veste, M., 2011. Differential hydrological response of biological topsoil crusts along a rainfall gradient in a sandy arid area: Northern Negev desert, Israel. Catena 87, 326-333. 
Table 1. Summary of statistical parameters of bare ground, bulk density and infiltrability at the unploughed-ungrazed, unploughed-grazed and ploughed-grazed sites. The different letters indicate different means at $\alpha=0.05$.

\begin{tabular}{|c|c|c|c|}
\hline Attribute & $\begin{array}{l}\text { Unploughed- } \\
\text { ungrazed }\end{array}$ & Unploughed-grazed & Ploughed-grazed \\
\hline \multicolumn{4}{|c|}{ Bare ground cover (\%) } \\
\hline Mean & 7.81 & 25.71 & 74.41 \\
\hline Median & $0.00^{\mathrm{a}}$ & $15.00^{\mathrm{b}}$ & $87.50^{c}$ \\
\hline SD & 19.69 & 28.45 & 30.80 \\
\hline $\mathrm{CV}$ & 252.31 & 110.65 & 41.40 \\
\hline \multicolumn{4}{|c|}{$\begin{array}{l}\text { Soil bulk density ( } \mathrm{Mg} \mathrm{m}^{-} \\
\text {3) }\end{array}$} \\
\hline Mean & 1.46 & 1.40 & 1.58 \\
\hline Median & $1.46^{\mathrm{a}}$ & $1.42^{\mathrm{b}}$ & $1.55^{\mathrm{c}}$ \\
\hline $\mathrm{SD}$ & 0.13 & 0.16 & 0.15 \\
\hline $\mathrm{CV}$ & 8.88 & 11.20 & 9.23 \\
\hline \multicolumn{4}{|c|}{ Infiltrability $\left(\mathrm{mm} \mathrm{h}^{-1}\right)$} \\
\hline Mean & 352.52 & 277.12 & 345.43 \\
\hline Median & $344.80^{\mathrm{a}}$ & $255.19^{b}$ & $324.34^{\mathrm{c}}$ \\
\hline SD & 104.37 & 126.86 & 131.61 \\
\hline $\mathrm{CV}$ & 29.61 & 45.78 & 38.10 \\
\hline
\end{tabular}


Table 2. Correlations of bare ground, bulk density and infiltrability at the unploughedungrazed, unploughed-grazed and ploughed-grazed sites. The correlations were calculated using a modified t-test that corrects the degrees of freedom based on the amount of autocorrelation in the data $* P<0.05$

\begin{tabular}{lcc}
\hline Treatment and attributes & Bare ground & Bulk density \\
\hline Unploughed-ungrazed & & \\
\hline Bulk density & 0.05 & \\
Infiltrability & 0.06 & 0.09 \\
Unploughed-grazed & & \\
Bulk density & $0.24^{*}$ & \\
Infiltrability & -0.02 & $-0.45^{*}$ \\
Ploughed-grazed & & \\
Bulk density & -0.01 & \\
Infiltrability & -0.20 & -0.13 \\
\hline
\end{tabular}


Table 3. Point biserial correlations between shrub cover versus bare ground cover, bulk density and infiltrability at the unploughed-ungrazed, unploughed-grazed and ploughedgrazed sites. ${ }^{*} P<0.05$

\begin{tabular}{lrcc}
\hline Treatments & $\begin{array}{c}\text { Bare ground } \\
\text { cover }\end{array}$ & Bulk density & Infiltrability \\
\hline Unploughed-ungrazed & $0.20^{*}$ & $-0.18^{*}$ & $0.38^{*}$ \\
Unploughed-grazed & -0.14 & $-0.48^{*}$ & $0.30^{*}$ \\
Ploughed-grazed & -0.07 & -0.12 & $0.40^{*}$ \\
\hline
\end{tabular}



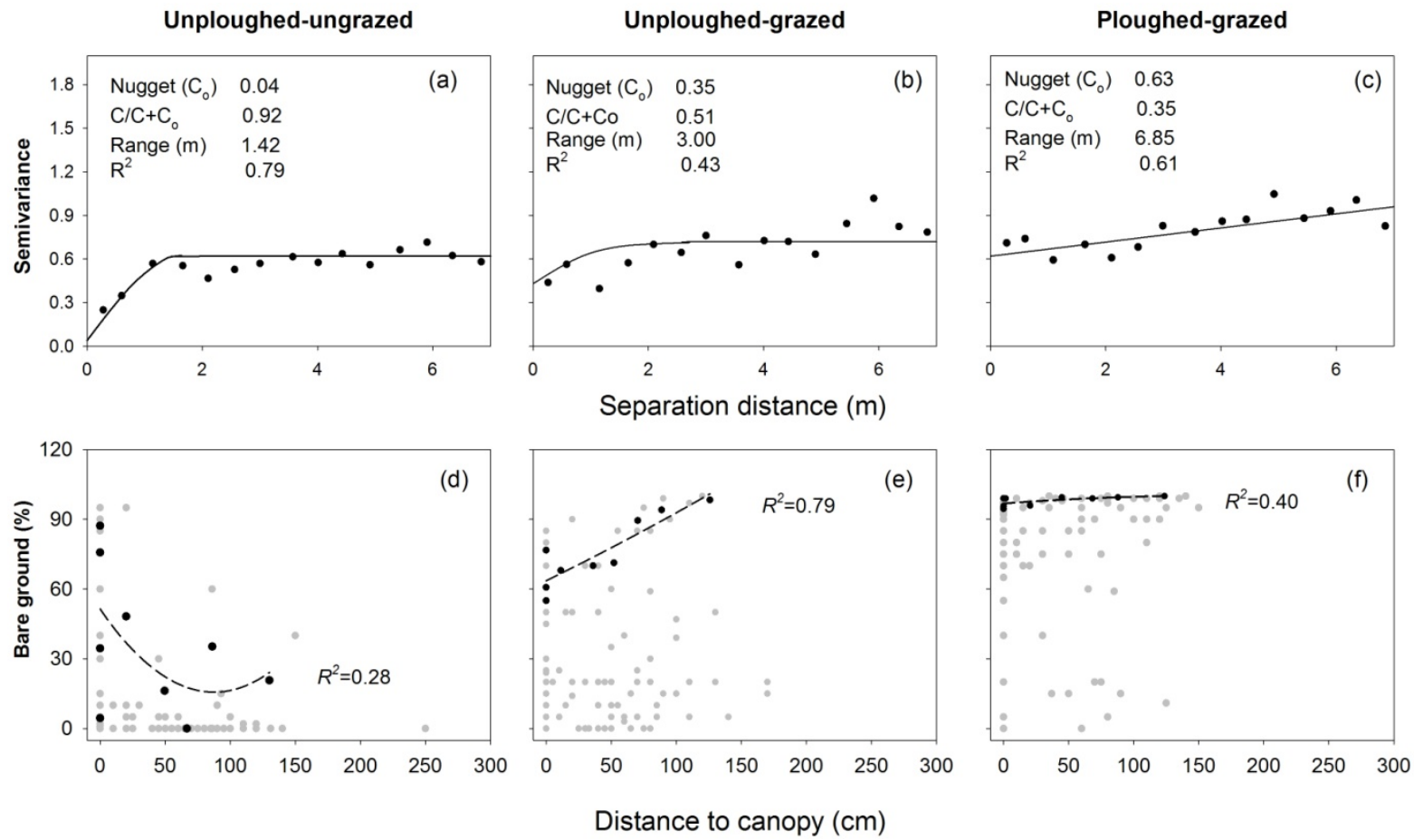

Figure 1. Semivariograms of bare ground (a-c) and segmented quantile regressions between bare ground and distance to canopy (d-f) at unploughed-ungrazed, unploughed-grazed and ploughed grazed sites. Black dots in graph $\mathrm{d}$, e, and $\mathrm{f}$ depict the $95^{\text {th }}$ quantiles of each class $(n=12)$ and segmented quantile regression lines (dashed) were delineated through those values. 

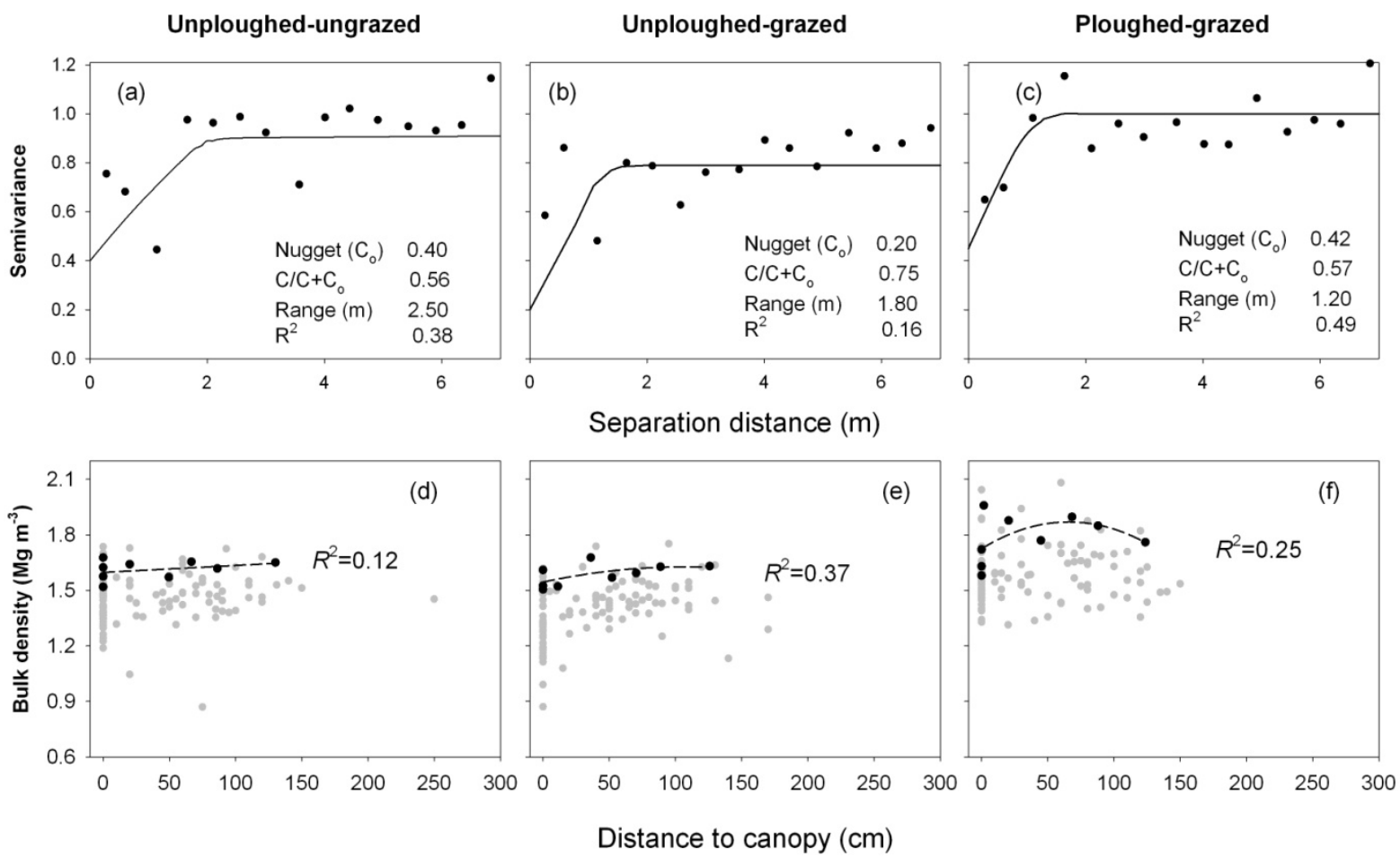

Figure 2. Semivariograms of bulk density (a-c) and segmented quantile regressions between bulk density and distance to canopy (d-f) at unploughed-ungrazed, unploughed-grazed and ploughed grazed sites. Black dots in graph $\mathrm{d}$, e, and $\mathrm{f}$ depict the $95^{\text {th }}$ quantiles of each class $(n=12)$ and segmented quantile regression lines (dashed) were delineated through those values. 

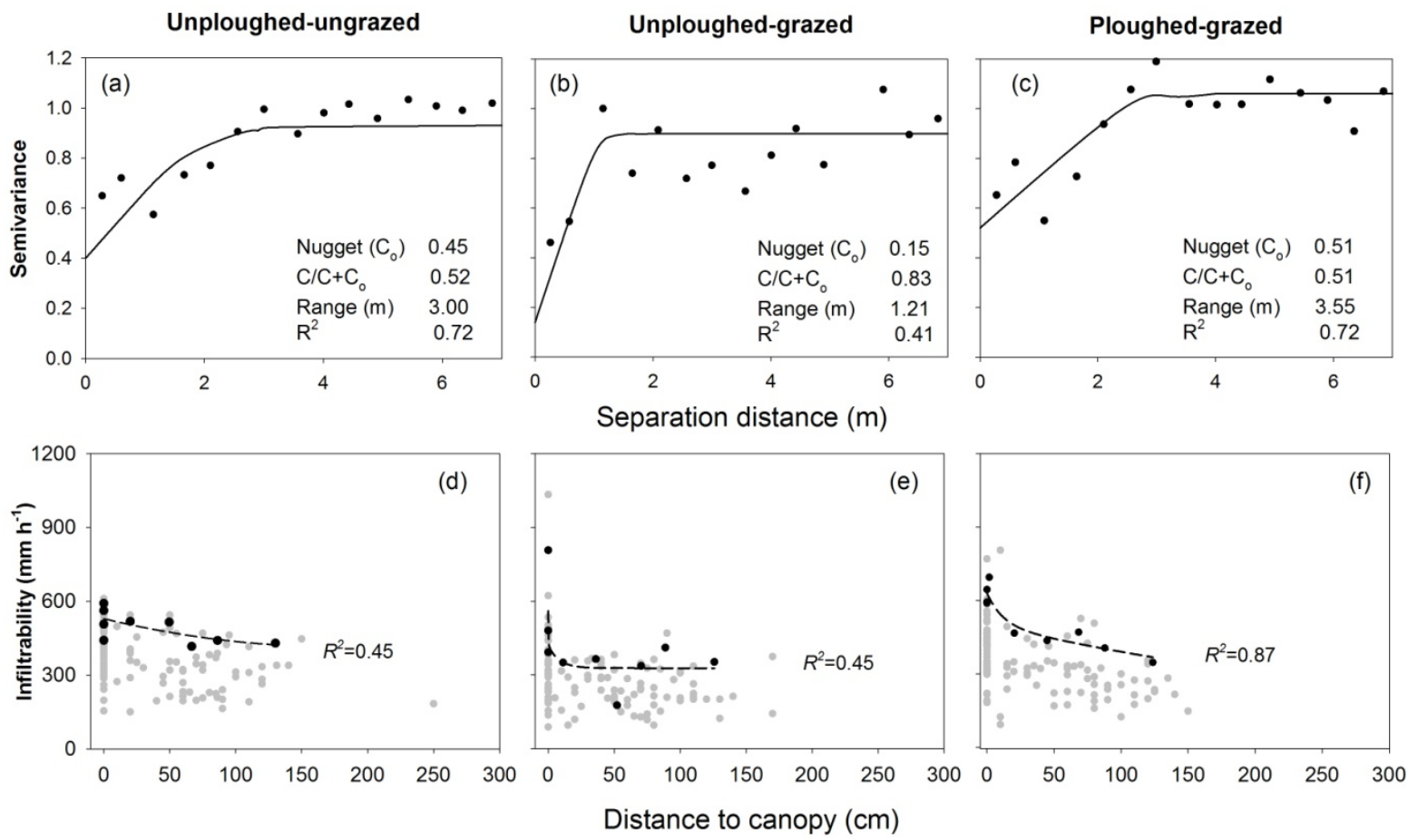

Figure 3. Semivariograms of infiltrability (a-c) and segmented quantile regressions between infiltrability and distance to canopy (d-f) at unploughed-ungrazed, unploughed-grazed and ploughed grazed sites. Black dots in graph $\mathrm{d}$, e, and $\mathrm{f}$ depict the $95^{\text {th }}$ quantiles of each class $(n=12)$ and segmented quantile regression lines (dashed) were delineated through those values. 


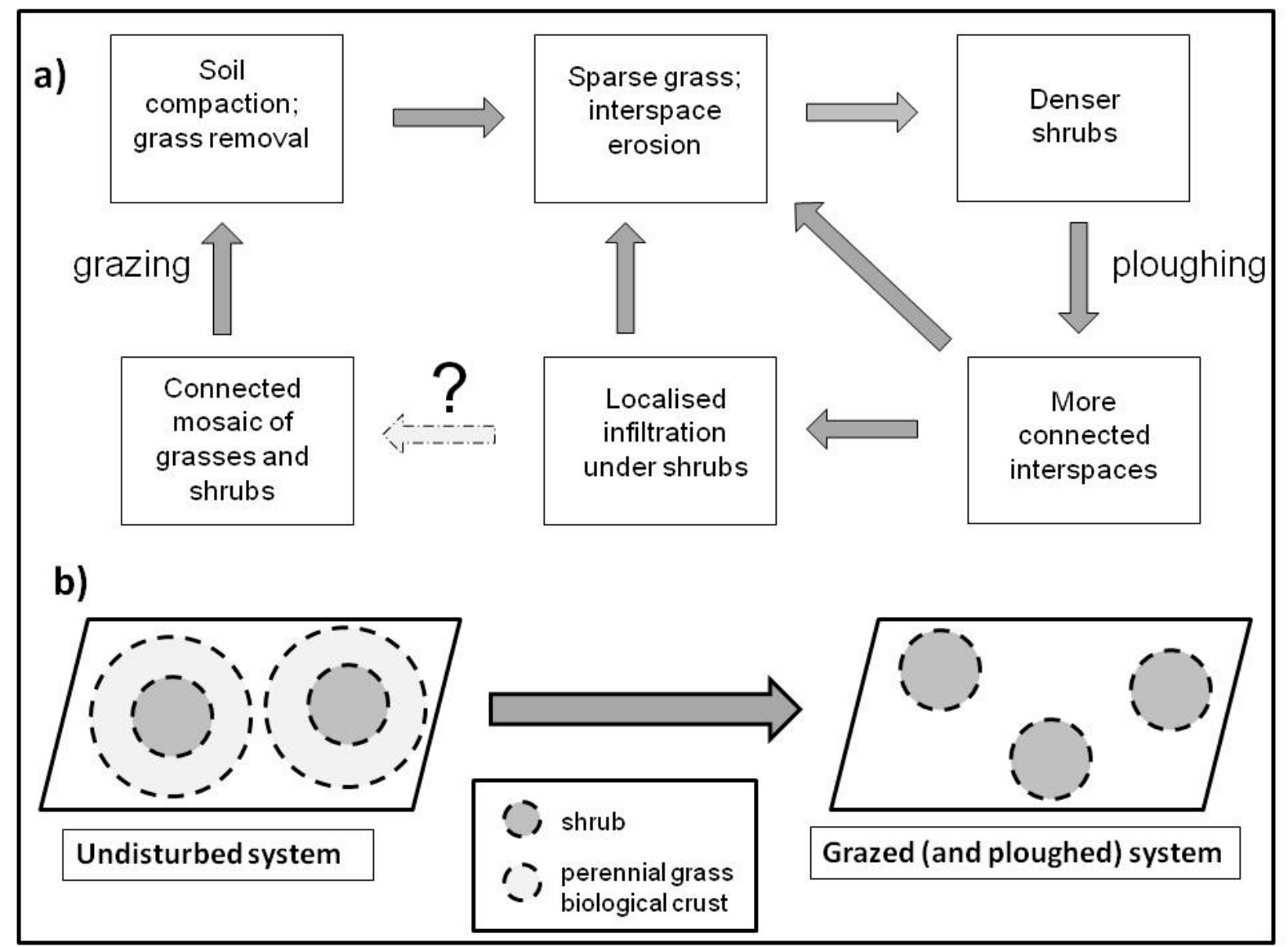

Figure 4. A conceptual model showing changes in: a) hydrological processes, and b) spatial distribution of infiltrability, driven by grazing and/or ploughing. Solid arrows in a) represent the degradation processes when disturbance occurs, while dashed arrow represents the likelihood that the disturbed state will not return to an undisturbed state. The shaded areas delineated by dashed circles in b) represent the areas influenced by grasses, biological soil crusts, and shrubs, while the white areas represent the plant- and crust-free interspaces. 


\section{Highlights}

- Spatial patterns of infiltrability changed with disturbance (i.e. grazing, ploughing)

- Infiltrability remained high beyond shrub canopy at the undisturbed site

- High infiltrability was enclosed within shrub canopy at the disturbed site

- The dichotomy between shrubs and their interspaces increased with disturbance 